\title{
Хірургічне лікування поєднаного оклюзійно-стенотичного ураження екстракраніальних артерій та аорто/клубово-стегнового сегмента в умовах високого ризику розвитку реперфузійно- реокигенаційних ускладнень
}

\begin{abstract}
Мета роботи: покращити результати хірургічного лікування поєднаного оклюзійно-стенотичного ураження екстракраніальних артерій та аорто/клубово-стегнового сегмента в умовах високого ризику розвитку реперфузійно-реоксигенаційних ускладнень. Матеріали і методи. Оперативні втручання виконано 47 пацієнтам із поєднаним ураженням екстракраніальних артерій та аорто/клубово-стегнового артеріального русла в умовах високого ризику розвитку реперфузійно-реоксигенаційних ускладнень. При поєднаному оклюзійно-стенотичному ураженні екстракраніальних артерій та аорто/клубово-стегнового сегмента в умовах ризику розвитку реперфузійно-реоксигенаційних ускладнень відновні операційні втручання необхідно здійснювати одномоментно: перший етап - реваскуляризація екстракраніальних артерій, другий - операційне втручання на аорто/клубовостегновому судинному руслі.

Результати досліджень та їх обговорення. При одномоментній реваскуляризації обох гемодинамічно значимих артеріальних сегментів вдається запобігти розвитку таких ускладнень, як прогресування ішемічних розладів мозкового кровотоку, поглиблення ішемії нижніх кінцівок, вираженої ниркової недостатності та деяких інших грізних реперфузійних ускладнень. Поряд із наведеним, на інтраопераційному етапі та у ранньому післяопераційному періоді діагностували один прояв транзиторної ішемічної атаки (розширене втручання на екстракраніальних судинах), 3 випадки порушення ритму і провідності серцевого м’яза та 2 прояви минущої ниркової недостатності.
\end{abstract}

Ключові слова: оклюзійно-стенотичне ураження; екстракраніальні артерії; аорто/клубово-стегновоий сегмент.

Постановка проблеми і аналіз останніх досліджень та публікацій. Особливістю атеросклеротичного процесу як системного захворювання є його мультифокальне оклюзійно-стенотичне ураження артеріального русла. Одночасно вражаючи декілька судинних басейнів, атеросклероз формує характерну клінічну картину ішемічних проявів різних органів і систем - від явної маніфестації до асимптомного, латентного перебігу в інших [1]. Найчастіше атеросклеротичне ураження локалізується в термінальному сегменті аорти, магістральній артерії нижніх кінцівок, коронарній артерії, гілках дуги аорти [2]. Патогенетична обгрунтованість та клінічна ефективність хірургічного лікування гемодинамічно значимих уражень магістральних артерій нижніх кінцівок, брахіоцефальних і коронарних артерій доведена в ряді досліджень [3]. На сьогодні дотримуються двох хірургічних тактик при реваскуляризаційних операційних втручаннях - одномоментна і поетапна [4]. Поряд $з$ цим невирішені питанням хірургічної тактики при поєднаному ураженні екстракраніальних артерій та аорто/клубово-стегнового сегмента в умовах високого ризику розвитку реперфузійнореоксигенаційних ускладнень.

Мета роботи: покращити результати хірургічного лікування поєднаного оклюзійно-стено- тичного ураження екстракраніальних артерій та аорто/клубово-стегнового сегмента в умовах високого ризику розвитку реперфузійно-реоксигенаційних ускладнень.

Матеріали і методи. Обстежено та оперовано 47 пацієнтів із поєднаним ураженням екстракраніальних артерій та аорто/клубово-стегнового артеріального русла. Вік хворих був в межах $52-73$ роки (середній вік - 63,5 \pm 7,4 року), всі пацієнти були чоловічої статі.

У 36 пацієнтів діагностовано різні варіанти атеросклеротичної оклюзії аорто/клубово-стегнового сегмента. 3 них у 21 хворого виявлено стенотично-оклюзивний процес стегно-підколінного сегмента обох нижніх кінцівок, а у 6 - стенотично-оклюзивний процес стегно-підколінного сегмента однієї нижньої кінцівки. Одна із нижніх кінцівок, переважно із багаторівневим стенотично-оклюзивним процесом, у пацієнтів із атеросклеротичною оклюзією аорто/клубово-стегнового сегмента характеризувалась IIIA-В ст. ХАН, контрлатеральна нижня кінцівка - IIA-В ст. ХАН (за класифікацією Fontaine R. з врахуванням критеріїв Європейської робочої групи (1992)).

У 11 пацієнтів встановлено різного рівня атеросклеротичну оклюзію клубового сегмента, а у 5 хво- 
рих 3 них діагностовано стенотично-оклюзивний процес стегно-підколінного сегмента. Відповідно вказана нижня кінцівка характеризувалась IIIA-B ст. ХАН, а контрлатеральна нижня кінцівка - IIA ст. ХАН (за класифікацією Fontaine R. з врахуванням критеріїв Європейської робочої групи (1992)).

Серед 47 пацієнтів у трьох встановлено поширений оклюзивно-стенотичний атеросклеротичний процес брахіоцефального стовбура (БЦС) та у трьох - стеноз (69 - 76 \%) біфуркації загальної сонної артерії (ЗСА) із поширенням на внутрішню сонну артерію (ВСА). Ізольоване ураження ВСА діагностовано у 41 пацієнтів (стеноз ВСА на рівні 64 - 90 \%). У 17 з них воно поєднувалось із стенотичним процесом контрлатеральної ВСА, у яких стенозування знаходилось на рівні 26 - 37 \%. У 19 (40,4 \%) пацієнтів встановлено компенсовану стадію недостатності мозкового кровообігу, у 28 (59,6 \%) - стадію відносної компенсації. Компенсована стадія недостатності мозкового кровообігу характеризувалась безсимптомним перебігом або ж початковими її проявами. Стадія відносної компенсації проявлялась минущими порушеннями мозкового кровообігу - у 9 (32,2 \%) спостереженнях, дисциркуляторною енцефалопатією - у 14 (50,0%) пацієнтів, а транзиторні ішемічні атаки (до двох епізодів) були у 5 (17,9 \%) хворих.

Для діагностики гемодинаміки екстракраніальних артерій застосовували ультразвукову систему “Ultramark - 9" (США) і “Doptek" (Англія), для діагностики гемодинаміки аорти та магістральних артерій нижніх кінцівок - ультразвукову систему Siemens Acuson S2000 (Німеччина). Для встановлення структурно-гемодинамічної характеристики аорти та магістральних артерій нижніх кінцівок використовували рентгеноконтрастну цифрову ангіографію.

У систему передопераційної підготовки введений комплекс профілактики реперфузійно-реоксигенаційних ускладнень, що включав: ліквідацію вазоконстрикції шляхом проведення пролонгованої епідуральної анестезії та інфузію простагландинів (алпростану, вазостенону); зниження нейтрофільної активності та рівня системної запальної відповіді за допомогою проведення сеансу лейкаферезу; підвищення опірності ендотелію шляхом призначення бета-блокатора (невибол), престаріуму та L-аргеніну; для нормалізації мікросудинної проникності призначали сольовий гіперосмотичний гіпертонічний розчин (декстран); підвищення активності прооксидантно-антиоксидантної рівноваги досягали введенням альфа-токоферолу та корвітину; для досягнення антиішемічного ефекту призначали внутрішньовенне введення рефортану.
Результати досліджень та їх обговорення. Вирішення черговості відновних операцій на брахіоцефальних артеріях і аорто/клубово-стегновому сегменті базувалось на аналізі локалізації оклюзивного процесу обох артеріальних басейнах, їх гемодинамічну характеристику, ступінь ішемії та толерантність головного мозку до ішемії. Проведення реваскуляризації тільки аорто/клубовостегнової зони у пацієнтів із ураженням екстракраніальних артерій може призвести до значних порушень мозкового кровотоку [4]. Враховуючи вказану обставину при поєднаному оклюзійностенотичному ураженні екстракраніальних артерій та аорто/клубово-стегновому сегменті в умовах високого ризику розвитку реперфузійно-реоксигенаційних ускладнень, існує необхідність одномоментного проведення відновного операційного втручання на обох артеріальних басейнах.

У 42 пацієнтів проведено одномоментне хірургічне втручання на екстракраніальних артеріях та аорто/клубово-стегновому сегменті. У всіх спостереженнях операційне втручання на екстракраніальних судинах проводили у вигляді каротидної ендартеректомії.

При поширеному оклюзійно-стенотичному ураженні БЦС і біфуркації ЗСА і ВСА в поєднанні із стенотичним процесом контрлатеральної ВСА у стадії відносної компенсації мозкового кровобігу у 6 пацієнтів першочергово було проведено оперативні втручання на судинах шиї. Здійснено два протезування при поширеному оклюзійностенотичном ураженні БЦС, резекцію каротидної біфуркації із реваскуляризацією сонних артерій шляхом протезування, сонно-підключичне автовенозне шунтування, ендартеректомію із БЦС та ендартеректомію із ЗСА, ендартеректомію із ПКА та підключично-сонне шунтування.

У 42 пацієнтів було проведено одномоментне хірургічне втручання на екстракраніальних артеріях та аорто/клубово-стегновому сегменті. У всіх спостереженнях операційне втручання на екстракраніальних судинах проводили у вигляді каротидної ендартеректомії.

30 пацієнтам одномоментно після оперативного втручання на екстракрніальних артеріях проведено аорто-біфеморальне алошунтування. Шести пацієнтам реваскуляризацію аорто-стегнової зони здійснено на 5 - 6 добу після відновного хірургічного втручання на артеріях шиї.

У 6 пацієнтів із однобічною оклюзією клубово-стегнового сегмента, у яких було виявлено стенотичний атеросклеротичний процес (64-81%) контрлатерального клубового сегмента, проведено аорто-біфеморальне алошунтування. П’ятьом 
іншим пацієнтам із однобічним ураженням клубово-стегнового сегмента виконано клубово-стегнове алошунтування. Всі наведені операційні втручання на аорто/клубово-стегновому артеріальному руслу здійснювали одномоментно відразу після закінчення реконструкції екстракраніальних артерій.

У 17 (65,4 \%) пацієнтів із 26, у яких оклюзивний процес аорто/клубово-стегнового сегмента поєднувався із стегно-дистальною оклюзією, на третю добу після операції при ультразвуковому дослідженні ПСШ і IP на рівні глибокої артерії стегна досягали рівня, відповідно, 23,2 - 1,5см/с і 0,41 0,29 у.о., а ПСШ і IP на рівні тібіоперинеального стовбура, відповідно, в межах 17,1-3,1 см/с і 0,39 - 0,11 у.о. Отримані результати нижчі, відповідно, у 1,9 (p < 0,05) i 1,5 (р < 0,05) раза за показники, що були на першу добу післяопераційного періоду. Подібне відбувається за рахунок блокування оклюзивним процесом стегно-підколінного сегмента анастомозів ГАС із низхідною артерією коліна та підколінною артерією. Вказані обставини були показанням до проведення стегно-дистальної реконструкції, що і було здійснено у 17 спостереженнях на третю добу після проведення відновної операцій на екстракраніальних та аорто/клубовостегнових артеріях.

Аналізуючи результати реваскуляризуючих операцій при поєднаному оклюзійно-стенотичному ураженні екстракраніальних артерій та аорто/ клубово-стегнової зони в умовах високого ризику розвитку реперфузійно-реоксигенаційних ускладнень встановлено, що завдяки одномоментній реваскуляризації обох гемодинамічних значимих артеріальних сегментів вдалось запобігти розвитку таких ускладнень, як прогресування ішемічних розладів мозкового кровотоку, поглиблення ішемії нижніх кінцівок, вираженої ниркової недостатності та деяких інших грізних реперфузійних ускладнень. Поряд із наведеним, на інтраопераційному етапі та у ранньому післяопераційному періоді діагностували один прояв транзиторної ішемічної атаки (розширене втручання на екстракраніальних судинах), 3 випадки порушення ритму і провідності серцевого м’яза та 2 прояви минущої ниркової недостатності.

\section{СПИСОК ЛІТЕРАТУРИ}

1. Технические аспекты реконструктивной хирургии сочетанных поражений сонных и позвоночных артерій / И. П. Додунов, О. Н. Бабак, Н. Л. Мячин, Б. С. Абу Азаб // Материалы юбилейной конференции посвященной 100-летию кафедр факультесткой хирургии и факультеской терапии Санк-Петербургского медицинского университета имени акад. И.П. Павлова. - СПб., 2000. - С. 159.
При поєднананому оклюзійно-стенотичному ураженні екстракраніальних артерій та аорто/клубово-стегнового сегмента в умовах ризику розвитку реперфузійно-реоксигенаційних ускладнень відновні операційні втручання необхідно здійснювати одномоментно: перший етап - реваскуляризація естракраніальних артерій, другий - операційне втручання на аорто/клубово-стегновому судинному руслі.

При проведенні операційного втручання на аорто/клубово-стегновому сегменті слід виконувати всі маніпуляції, які спричиняють зниженню сили ударної хвилі на периферійне артеріальне русло; реваскуляризацію аорто/клубово-стегнового сегмента здійснювали тільки шляхом аорто/клубово-біфеморального алошунтування; в умовах однобічної оклюзії клубово-стегнового сегмента при стенотичному процесі (64 - 81 \%) контрлатеральної клубової зони слід здійснювати аорто-біфеморальне алошунтування; після сформування аортобіфеморального алошунта першим відновлюється кровоток по непроблемній нижній кінцівці.

Відстрочена реваскуляризації стегно-дистального артеріального русла на третю добу після аорто/клубово-біфеморального алошунтування має рад позитивних рис: окрім відновлення повноцінного кровопостачання дистальних відділів нижньої кінцівки, запобігає раптовому кисневому удару по периферійній артеріальній системі нижньої кінцівки.

Висновки. При поєднаному атеросклеротичному ураженні екстракраніального та аорто/клубово-стегнового артеріального русла в умовах високого ризику розвитку реперфузійно-реоксигенаційних ускладнень слід проводити одномоментно відновні операції на обох гемодинамічно значимих артеріальних сегментах.

Застосування одномоментного відновлення реваскуляризації атеросклеротичного ураження екстракраніального та аорто/клубово-стегнового артеріального русла попереджує розвиток ряду ускладнень; розвиток гострих ішемічних розладів мозкового кровотоку, поглиблення ішемії нижніх кінцівок, вираженої ниркової недостатності та деяких інших грізних реперфузійних ускладнень.

2. Тактика лечения мультифокального атеросклероза / П. И. Никульников, А. В. Ратушняк, С. Н. Фуркало [и др.] // Вісник Української медичної стоматологічної академії. 2015. - Т. 9, №1. - С. 318-321.

3. Тугеева Э. Ф. Определение приоритетности поражения различных артериальных бассейнов у больных с тяжелыми формами мультифокального атеросклероза : автореф. дисс. 
на соискание науч. степени канд. мед. наук : 140006 Науч. центр сердечно-сосудистой хирургии им. А. Н. Бакулева РАМН / Тугеева Э. Ф. - М., 2002. - 24 с.

4. Hallett J. V. Selection and preparation of high-risk patient for repair of abdominal aortic aneurysm / J. V. Hallett, T. C. Bower, K J. Cherry

\section{REFERENCES}

1. Dudanov, I.P., Babak, O.N., Myachin, N.L., \& Abu Azab, B.S. (2000). Tekhnicheskiye aspekty rekosntruktivnoy khirurgii sochetannykh porazheniy sonnykh i pozvonochnykh arteriy [Technical aspects of reconstructive surgery of combined lesions of the carotid and vertebral arteries]. Materialy yubileynoy konferentsii posvyashchennoy 100-letiyu kafedr fakultestkoy khirurgii $i$ fakulteskoy terapii Sankt-Peterburgskogo meditsinskogo universiteta imeni akad. I.P. Pavlova - Proceedings of the Jubilee Conference dedicated to the 100th anniversary of the Department of Faculty Surgery and Faculty Therapy of the St. Petersburg Medical University named after acad. I.P. Pavlov. Saint-Petersburg [in Russian].

2. Nikulnikov, P.I., Ratushnyak, A.V., Furkalo, S.N., Guch, A.A., \& Liksunov A.V. (2015). Taktika lecheniya multifokalnogo ateroskleroza [Tactics of treatment of multifocal atherosclerosis]. Visnyk Ukrainskoi medychnoi stomatolohichnoi akademii - Bulletin of the Ukrainian Medical and Dental Academy, 9, 1, 318-321 [in Russian].
// Mayo Clin. Proc. - 2004. - Vol. 69, No. 6. - P. 763-768.

5. Ковальчук Л. Я. Хірургія поєднаних і множинних атеросклеротичних оклюзій екстракраніальних артерій та аортостегнового сегмента / Л. Я. Ковальчук, І. К. Венгер, С. Я. Костів. - Тернопіль : «Укрмедкнига, 2005. - С. 198

3. Tugeyeva, E.F. (2002). Opredeleniye prioritetnosti porazheniya razlichnykh arterialnykh basseynov u bolnykh s tyazhelymi formami multifokalnogo ateroskleroza [Prioritization of damage to various arterial pools in patients with severe forms of multifocal atherosclerosis.]. Candidate's thesis. Moscow: A. N. Bakulev Scientific Center of Cardiovascular Surgery [in Russian].

4. Hallett, J.V., Bower, T.C., \& Cherry, K.J. (2004). Selection and preparation of high-risk patient for repair of abdominal aortic aneurysm. Mayo Clin. Proc., 69, 6, 763-768.

5. Kovalchuk, L.Ia., Venher, I.K., \& Kostiv, S.Ia. (2005). Khirurhiia poiednanykh i mnozhynnykh aterosklerotychnykh okliuzii ekstrakranialnykh arterii ta aorto-stehnovoho sehmentu [Surgery of combined and multiple atherosclerotic occlusions of extracranial arteries and aorto-femoral segments]. Ternopil: Ukrmedknyha [in Ukrainian].

Отримано 29.01.2019

Електронна адреса для листування: venger@tdmu.edu.ua ; herasymyuk_n@tdmu.edu.ua; kostivsj@tdmu.edu.ua; vayda@tdmu.edu.ua; loikoii@tdmu.edu.ua

I. K. VENHER, N. I. HERASYMIUK, S. YA. KOSTIV, A. R. VAYDA, I. I. LOYKO

I. Horbachevsky Ternopil State Medical University

\title{
SURGICAL TREATMENT OF THE COMBINED OCCLUSAL-STENOTIC AFFECTION OF EXTRACRANIAL ARTERIES AND AORTO/ILIAC-FEMORAL SEGMENT IN CONDITIONS OF HIGH RISK OF DEVELOPMENT OF REPERFUSION-REOXIGENATION COMPLICATIONS
}

\begin{abstract}
The aim of the work: to improve the results of surgical treatment of combined occlusion-stenotic lesions of extracranial arteries and the aorto/iliac-femoral segment in conditions of high risk of development of reperfusion-reoxygenative complications.

Materials and Methods. There were operated 47 patients with combined lesions of extracranial arteries and aorto/iliac-femoral arterial beds in conditions of high risk of reperfusion-reoxygenative complications. At combined occlusal-stenotic lesions of extracranial arteries and aorto/iliac-femoral segment in conditions of risk of reperfusion-reoxygenative complications, restorative surgical interventions should be performed simultaneously: the first stage is the revascularization of the extracranial arteries, the second is surgical intervention on the aorto/iliac-femoral vessels.

Results and Discussion. With simultaneous revascularization of both hemodynamically significant arterial segments, it is possible to prevent the development of complications such as progression of ischemic cerebrovascular disorders, deepening of lower limb ischemia, severe renal failure and some other formidable reperfusion complications. Along with the above, at the intraoperative stage and in the early postoperative period, one manifestation of transient ischemic attack (extended intervention in extracranial vessels), 3 cases of rhythm and cardiac conduction impairment and 2 manifestations of transient renal failure were diagnosed.
\end{abstract}

Key words: occlusion-stenotic lesion; extracranial arteries; aorto/iliac-femoral segment. 
И. К. ВЕНГЕР, Н. И. ГЕРАСИМЮК, С. Я. КОСТИВ, А. Р. ВАЙДА, И. И. ЛОЙКО

гВУЗ “Тернопольский государственный медицинский университет имени И. Я. Горбачевского МОЗ Украины”

\section{ХИРУРГИЧЕСКОЕ ЛЕЧЕНИЕ КОМБИНИРОВАННОГО ОКК.ЛЮЗИОННО-СТЕНОТИЧЕСКОГО ПОРАЖЕНИЯ ЭКСТРАКРАНИАЛЬНЫХ АРТЕРИЙ И АОРТО/ПОДВЗДОШНО-БЕДРЕННОГО СЕГМЕНТА В УС.ЛОВИЯХ ВЫСОКОГО РИСКА РАЗВИТИЯ РЕПЕРФУЗИОННО- РЕОКСИГЕНАЦИОННЫХ ОС.ЛОЖНЕНИЙ} экстракраниальных артерий и аорто/подвздошно-бедренного сегмента в условиях высокого риска развития реперфузионнореоксигенационных осложнений.

Материалы и методы. Оперированы 47 пациентов с сочетанным поражением экстракраниальных артерий и аорто/подвздошнобедренного артериального русла в условиях высокого риска развития реперфузионно-реоксигенационных осложнений. При сочетанном окклюзионно-стенотическом поражении экстракраниальных артерий и аорто/подвздошно-бедренного сегмента в условиях риска развития реперфузионно-реоксигенационных осложнений восстановительные оперативные вмешательства необходимо осуществлять одномоментно: первый этап - реваскуляризация эстракраниальних артерий, второй - оперативное вмешательство на аорто/подвздошно-бедренном сосудистом русле.

Результаты исследований и их обсуждение. При одномоментной реваскуляризации обеих гемодинамически значимых артериальных сегментов удается предотвратить развитие таких осложнений, как прогрессирование ишемических нарушений мозгового кровотока, углубление ишемии нижних конечностей, выраженной почечной недостаточности и других грозных реперфузионных осложнений. Наряду с приведенным на интраоперационном этапе и в раннем послеоперационном периоде диагностировали одно проявление транзиторной ишемической атаки (расширенное вмешательство на экстракраниальных сосудах), 3 случая нарушения ритма и проводимости сердечной мышцы и 2 проявления проходящей почечной недостаточности.

Ключевые слова: окклюзионно-стенотические поражения; экстракраниальные артерии; аорто/подвздошно-бедренный сегмент. 